v. $13, n .2$

Vitória-ES, Mar.-Apr. 2016

p. 135 - $157 \quad$ ISSN 1808-2386 DOI: http://dx.doi.org/10.15728/bbr.2016.13.2.6

\title{
Motivations, Risks, Barriers, and Results Associated with the Adoption of Global Sourcing by Brazilian Companies: a Case-Based Study
}

\author{
Moema Pereira Nunes ${ }^{\dagger}$ \\ Pontifícia Universidade Católica do Rio Grande do Sul - PUCRS
}

\begin{abstract}
This article aims to identify the motivations behind global sourcing (GS) adoption, the associated risks and barriers, and the results that companies from emerging countries are achieving. The research explores the distinguishing features of these companies' experience and examines established theories about GS that are based on companies from developed countries. In the article, a case-based study investigated four companies from the electrical and electronics industry in South Brazil. Data were collected through in-depth interviews, documents, and direct observation. According to the research, the main motivations for adopting GS are faster access to new technologies and establishing a presence in global markets. It was also found that the opportunity to offer diversified products using the distribution channels already developed by companies motivates GS adoption, a situation that prior literature has not identified. Despite the risks, the absence of a broad local supply-base prompts companies to adopt GS. Further, the failure to formalize barrier analysis processes creates difficulties for companies. The main results associated with GS relate to innovation and reductions in the time taken to develop products and reach markets. In this regard, companies face a challenge to develop the abilities required to compete for the advantages that the global market can offer.
\end{abstract}

Keywords: Sourcing. Global sourcing. Global supply chain strategies. Brazil. Electrical and electronics industry.

Received on 10/13/2014; reviewed on 10/30/2014; accepted on 11/03/2014; published on 03/01/2016.

*Author for correspondence::

${ }^{\dagger}$. PhD in Business Administration from Universidade do Vale do Rio dos Sinos ( UNISINOS )

Link: Professor of School of Business Administration, Accounting and Economics at the Pontifical Catholic University of Rio Grande do Sul ( PUCRS )

Address: Av Ipiranga 6681 , Building 50 , 10 floor, Porto Alegre - RS - Brazil - CEP 90619-900 .

E-mail: moemanunes@hotmail.com

Phone: (51) 91250983

Note from the Editor: This paper was accepted by Bruno Felix. 


\section{INTRODUCTION} opportunity to achieve competitive advantage. Primarily, it is associated with a lack of local suppliers (of products, services, and technology) or lower acquisition costs. These reactive motivations have been moving toward a more proactive strategy (MONCZKA; TRENT, 1991; BOZARTH; HANDFIELD; DAS, 1998; HARRIS, 2006; KNUDSEN; SERVAIS, 2007; DUTTON, 2008). In this regard, sourcing refers to a company's functional activity to access external resources such as raw materials, finished goods, and services. However, the term "global sourcing" (GS) has emerged as representative of the approach to adopting strategic sourcing on a global basis. Thus, GS refers to a company's strategic intention to search for and monitor global supply markets. It also refers to the efficient management of such activities through the integration and coordination of work related to the functional areas (NUNES; VIEIRA; ANTUNES JR., 2013).

GS started among companies operating in the U.S., Europe, and Japan. More recently, companies from emerging countries have developed GS practices. Such companies are facing a more competitive environment and faster growth processes. Even for those that have been used to making international purchases, long-term consolidation of this activity into their strategic plans is becoming more prevalent. This situation results in companies facing challenges during GS adoption. Companies from emerging countries are growing quickly at a time when they have greater access to technologies and communication tools, and in this context the establishment of complex governmental agreements can both facilitate and impose barriers on international trade. Moreover, companies from emerging countries are undergoing rapid internationalization processes characterized by bold and aggressive actions (SIRKIN et al., 2008). In addition, the competitive advantages of such companies are usually related to price competition, which is more difficult to sustain than technology or brand-related advantages (GAMMELTOF; BARNARD; MADHOCK, 2010). According to Gammeltof, Barnard, and Madhock (2010), the trajectories followed by companies from emerging countries often differ from those followed by companies from developed countries.

GS studies have focused on the investigation of companies in developed countries (TRENT; MONCZKA，1991，2003，2003A; NARASIMHAN; CARTER, 1998; SAMLI; BROWING，2003; KOTABE; MURRAY，2004; KOCABASOGLU; SURESH, 2006; NASSIMBENI, 2006; NASSIMBENI; SARTOR， 2007; TRAUTMANN; BALS; 
HARTMANN, 2009). Developing and emerging countries are usually investigated as suppliers for these companies, not as the companies' countries of origin (NASSIMBENI; SARTOR, 2007; LAHIRI; KEDIA, 2009; TOWERS; SONG, 2010). In this regard, emerging countries are usually characterized as having more active participation from governments in their economies and less sophisticated economic institutional environments. Their companies tend to operate in more mature industries rather than technological industries and exhibit variations according to local institutional contexts; for example, emerging companies are often state-owned, affiliated, or family-owned (GAMMELTOF; BARNARD; MADHOCK, 2010). They face competition from companies in developed economies and tend to use each other as points of reference in their internationalization decisions (LI; YAO, 2010).

In order to understand this situation more clearly, it is worth asking the following question: Are there differences in GS adoption by companies from emerging countries in terms of motivations, risks, barriers, and results? In order to answer the question, this paper aims to identify the motivations behind GS adoption, the barriers and risks that are faced while engaging in such adoption, and the results that companies are achieving.

Samli, Browning, and Busbia (1998) reveal the need for studies that investigate GS adoption and that include reviews of business involvement in the processes and the incorporation of such adoption into corporate strategic planning. By investigating emerging issues in the supply of resources, Sheth and Sharma (1997) determine that GS activities should be explored further because of the opportunity to obtain a competitive advantage through this strategy. At the same time, these authors highlight that cultural and legal differences among countries are critical factors that relate directly to GS. Although such authors arrived at their conclusions several years ago, this need for investigation still exists, as identified by Kausik and Mahadevan (2012). They argue that GS is far more complex than current studies suggest because contextual aspects can influence it. The same authors also argue that more qualitative research is needed in order to enable researchers to forecast future directions. Such research should include the establishment of a new agenda that includes future trends in procurement and possible trajectories for an organization to take.

In order to conduct the research in this article, a brief discussion about GS and the companies of emerging countries will first be presented. The conceptual framework will then be given followed by the research design. The research results will be described in three sections: motivations, risks and barriers, and results. After this, the article will present the 
final discussion, theoretical and managerial implications, study limitations, and future research directions.

\section{GLOBAL SOURCING AND THE COMPANIES OF EMERGING COUNTRIES}

The search for opportunities to source globally requires purchasing companies to adopt a different approach. For example, the ability to visualize the entire world as a potential supplier of raw materials, components, finished goods, and services can be regarded as a prerequisite to GS (MONCZKA; TRENT, 1991). At the same time, greater knowledge of purchasing is required, including an awareness of the greater risks associated with such purchasing activities (KOTABE; MURRAY, 2004). As Butter and Linse (2008) emphasize, companies have begun to add value through the optimal orchestration of their foreign suppliers. However, arranging such orchestration requires companies to employ a strategic approach; thus, the process of sourcing in enterprises has recently achieved strategic status (QUINTENS; PAUWEL; MATTHYSSENS, 2006).

The traditional relationships established by companies from developed countries with suppliers abroad were based primarily on the sourcing companies' supplier dependence. However, companies from developing countries now have the opportunity to achieve higher production levels through their sourcing activities. Further, sourcing companies used to be larger than their suppliers as well as more technologically advanced and with more sophisticated management processes.

Companies from emerging countries can face the same situations as their suppliers, especially when they work with small suppliers from their home countries or other developing countries. However, different types of relationship can also be developed by these companies. In some cases, they can establish relationships with suppliers that have the same size and characteristics; that is, other companies from emerging countries. In these cases, the dependence relationship may not exist (when other suppliers and buyers are available) or could exist for buying and supplying companies at the same time. A third possible type of relationship occurs when companies from emerging countries have suppliers with greater bargaining power (usually companies from developed countries or stronger companies from their home or host countries). In this case, a dependence relationship with the supply source will exist. The choice between these different types of relationship will vary according to the structure of a company and industry, and the three different paths must be considered new challenges in sourcing strategy development. 
In an examination of Brazilian late movers, Rocha, Silva, and Carneiro (2007) find that the transition of Brazilian companies took place later compared with companies from other Latin American countries. Further, Barreto and Rocha (2003) argue that the internationalization process occurred later in Brazil because of: (1) the country's size, which provides a large internal market; (2) the lack of governmental support for the establishment of international operations; (3) the protection of the country's domestic market until the beginning of the 1990s; and (4) Brazil's cultural distance from other countries. In this context, according to Borini et al. (2007), three factors have contributed to the success of late movers: (1) a global mindset, (2) bold decisions, and (3) the realignment of the entire company in order to compete on a global scale.

\section{CONCEPTUAL FRAMEWORK}

The conceptual framework that was developed in order to conduct this research includes four dimensions: (1) motivations, (2) risks, (3) barriers, and (4) results. The first dimension, motivations, is defined as what encourages companies to capture local cost advantages and to offset competitive disadvantages through the use of foreign suppliers. Based on this concept, two constructs were identified: motivations related to comparative advantages (total cost reduction) and motivations related to competitive advantages. This second type of motivation was separated into product-related, supplier-related, process-related, and company-related aspects. The second dimension, risks, focuses on the potential negative effects during GS adoption. In such a context, this research considers the negative aspects of GS that are reflected in the buying company. Thus, risks were divided into four constructs: environmental analysis and trade-off analysis, the development of alternative sourcing opportunities, the balance between local and global sourcing, and risk management. With regard to barriers, the third dimension, this research considers the factors that make the adoption of GS more difficult or even impossible to pursue or intensify. Thus, barriers were divided into a matrix that considers internal and external barriers set against the relation with product, company/management, networks, industry/competition, and environment. The research adopted this different approach in order to apply the concepts of Alguire, Frear, and Metcalf (1994) and Quintes, Pauwels, and Matthyssens (2006) more effectively. The fourth dimension is results, which are the benefits that companies can achieve through GS adoption. Results were divided into three constructs: product-related, process-related, and knowledge-related. All the dimensions and constructs are presented in Table 1 together with the main references used to establish them. 


\begin{tabular}{|c|c|c|}
\hline Dimensions & Constructs & Main references \\
\hline \multirow[t]{2}{*}{ Motivations } & Motivations related to comparative advantages & \multirow[b]{2}{*}{$\begin{array}{l}\text { Monczka and Trent (1991); Bozarth, } \\
\text { Handfield, and Das (1998); Cho and } \\
\text { Kang (2001); Christopher (2002); Jin } \\
\text { (2004); Agndal (2006); Harris } \\
\text { (2006); Knudsen and Servais (2007); } \\
\text { Dutton (2008) }\end{array}$} \\
\hline & $\begin{array}{l}\text { Motivations related to competitive advantages: } \\
\text { Product-related } \\
\text { Supplier-related } \\
\text { Process-related } \\
\text { Company-related }\end{array}$ & \\
\hline \multirow[t]{4}{*}{ Risks } & Environmental analysis and trade-off analysis & \multirow{4}{*}{$\begin{array}{l}\text { Levy (1995), Bozarth, Handfield, and } \\
\text { Das (1998); Cho and Kang (2001); } \\
\text { Zeng and Rosseti (2003); } \\
\text { Christopher, Peck, and Towill } \\
\text { (2006); Butter and Linse (2008); } \\
\text { Steinle and Schiele (2008) }\end{array}$} \\
\hline & Development of alternative sourcing opportunities & \\
\hline & Balance between local and global sourcing & \\
\hline & Risk management & \\
\hline \multirow[t]{2}{*}{ Barriers } & Internal and external barriers & \multirow{2}{*}{$\begin{array}{l}\text { Alguire, Frear, and Metcalf (1994); } \\
\text { Quintes, Pauwels, and Matthyssens } \\
\text { (2006) }\end{array}$} \\
\hline & $\begin{array}{l}\text { Product-related } \\
\text { Company/management-related } \\
\text { Networks-related } \\
\text { Industry/competition-related } \\
\text { Environment-related }\end{array}$ & \\
\hline Results & $\begin{array}{l}\text { Product-related } \\
\text { Process-related } \\
\text { Knowledge-related }\end{array}$ & $\begin{array}{l}\text { Trent and Monczka (2003); } \\
\text { Quintens, Pauwells, and Matthyssens } \\
\text { (2006); } \\
\text { Mulani (2008) }\end{array}$ \\
\hline
\end{tabular}

Table 1 - Dimensions, constructs, and main references

\section{RESEARCH DESIGN}

A qualitative case-based study was developed in order to answer the research question. A qualitative case study can be defined as empirical research that primarily uses contextually rich data from bounded real-world settings in order to investigate a focused phenomenon (BARRAT; CHOI; LI, 2011). Case studies attempt to clarify a decision or a set of decisions and include what motivated the decisions and the results that were achieved (Schramm, 1971). The choice of qualitative research is related to the fact that a quantitative study would not allow us to have an in-depth analysis of the internationalization of the investigated companies' sourcing activities. A case research methodology is "both appropriate and essential where either theory does not exist or is unlikely to apply ..., [and] where theory exists but the environmental context is different" (STUART et al., 2002: 423). It is also appropriate when the research focus relies on the exploration and better understanding of emerging, contemporary phenomena or issues in their real world settings (BARRAT; CHOI; LI, 2011).

In this context, the first layer of scope was the selection of Brazilian companies from the electrical and electronics industry in Brazil's Rio Grande do Sul state. The electrical and electronics industry in Brazil can be regarded as an import industry. From 2003 to 2010, total imports in this sector increased by 47\%, representing USD 24.882 million. The importance of imported goods in this industry can also be seen in the percentage of imports within the internal market for end-products. This figure reached $21.6 \%$ in 2010. 
The state of Rio Grande do Sul has the second-largest cluster of companies working in the Brazilian electrical and electronics industry. Most of these companies are financed by local capital. The decision to investigate companies from this state was made because its industry is well structured and the companies are organized in an industry association. Before each company was investigated, documents from the association had already shown the importance of GS in the industry.

The second layer of scope was related to the selection of companies that, according to Trent and Monczka's (2003) framework, were adopting GS. Using this framework, a meeting was arranged with the industry association. The theoretical concept was presented to the association's directors and they were asked to identify companies that could be positioned at each level of the continuum. Each choice was discussed in order to understand the company. In this way, a group of suitable companies was identified. The association sent emails to the companies, presenting the research project and asking senior managers if they would take part in the research. The support of the association was fundamental in order to access these senior managers. The companies were then selected according to convenience and availability.

Table 2 presents a brief description of the studied companies. These companies have similarities: they were founded in the 1980s and the 1990s; they tend to obtain supplies from emerging and developed countries at the same time; and as exporters, they have a more intense market share in Latin America. The companies agreed to participate if they could remain anonymous. The presentation of them focused on their sourcing strategies and activities, not on their histories and general business strategies. 


\begin{tabular}{|c|c|c|c|c|}
\hline & Company A & Company B & Company C & Company D \\
\hline $\begin{array}{l}\text { Decade of } \\
\text { foundation: }\end{array}$ & $1980 \mathrm{~s}$ & $1980 \mathrm{~s}$ & $1990 \mathrm{~s}$ & $1990 \mathrm{~s}$ \\
\hline Size of company: & $\begin{array}{l}1 \text { - } 99 \\
\text { employees }\end{array}$ & $\begin{array}{l}250 \text { - } 499 \\
\text { employees }\end{array}$ & $\begin{array}{l}100 \text { - } 249 \\
\text { employees }\end{array}$ & 100 - 249 employees \\
\hline $\begin{array}{l}\text { Purchase offices } \\
\text { abroad/year } \\
\text { operations began: }\end{array}$ & None & $\begin{array}{l}\text { Purchase office - } \\
\text { Germany, } 2008\end{array}$ & None & $\begin{array}{l}\text { Purchase office - } \\
\text { China, } 2010\end{array}$ \\
\hline $\begin{array}{l}\text { Typology of purchase } \\
\text { items (components, } \\
\text { finished products): }\end{array}$ & $\begin{array}{l}\text { Components } \\
\text { and finished } \\
\text { products }\end{array}$ & $\begin{array}{l}\text { Components and } \\
\text { finished products }\end{array}$ & Components & $\begin{array}{l}\text { Components and } \\
\text { finished products }\end{array}$ \\
\hline $\begin{array}{l}\text { \% of sourcing made } \\
\text { abroad (compared } \\
\text { with total } \\
\text { purchased): }\end{array}$ & $\begin{array}{l}2007-2 \% \\
2008-5 \% \\
2009-10 \% \\
2010-15 \% \\
2011-20 \%\end{array}$ & $\begin{array}{l}2007-37 \% \\
2008-46 \% \\
2009-39 \% \\
2010-36 \% \\
2011-35 \%\end{array}$ & $\begin{array}{l}2007-12.57 \% \\
2008-15.99 \% \\
2009-29.38 \% \\
2010-39.05 \% \\
2011-60.79 \%\end{array}$ & $\begin{array}{l}2007-5 \% \\
2008-5 \% \\
2009-5 \% \\
2010-5 \% \\
2011-5 \%\end{array}$ \\
\hline $\begin{array}{l}\text { \% intra-company } \\
\text { sourcing made } \\
\text { abroad: }\end{array}$ & None & $1 \%$ & None & $5 \%$ \\
\hline Countries of supply: & $\begin{array}{l}\text { China } \\
\text { Taiwan } \\
\text { Hong Kong } \\
\text { Germany }\end{array}$ & $\begin{array}{l}\text { United States } \\
\text { China } \\
\text { Germany }\end{array}$ & $\begin{array}{l}\text { China } \\
\text { United States }\end{array}$ & $\begin{array}{l}\text { United States } \\
\text { China } \\
\text { Taiwan }\end{array}$ \\
\hline
\end{tabular}

Table 2 - Company descriptions

Evidence was collected from documents, interviews, and direct observation. The documents were used to corroborate and enhance the evidence from other sources, with particular attention paid to the structured interviews. Reports from the companies, the industry association, and the regional government were also used. The interviews were spontaneous and allowed the researcher to ask the participants about key facts as well as their opinions on certain issues. The interviews were in-depth and conducted in 2011 and 2012. All of them were recorded and transcribed. One interview was conducted with the owner/manager of each company. At Company A, the interviewee was the owner/director who had worked there since the company's foundation. The interview lasted two hours 33 minutes. At Company B, we interviewed the manager, who had worked there for 13 years, and the supervisor, who had worked there for 10 years. They were interviewed together for two hours 19 minutes. At Company $\mathrm{C}$, the controller and manager were interviewed together for two hours 25 minutes. They had both worked at Company $\mathrm{C}$ for 14 years. At Company D, the interviewee was the owner/director, who had worked there for 12 years. The interview lasted two hours 10 minutes.

The third source of evidence was direct observation, which was conducted either before or after the interviews during visits to each company's site. Content analysis was then undertaken. Content analysis is a research procedure that is applied in order to analyze data, especially data obtained from interviews. NVivo® software was used to conduct the data 
analysis. The constructs identified at the conceptual model stage were used as tags to select related parts of the interviews. The fragments were read several times in order to extract conclusions about each construct. Parts of the documents were tagged again as new knowledge was discovered during the study. This new knowledge was considered, and after an in-depth investigation new tags were created. Each interview description was then read again in order to identify new fragments related to the new tags. Information from the companies' documents and the direct observations were also included on the NVivo ${ }^{\circledR}$ database and a similar tagging process was undertaken.

\section{- Motivations to adopt GS}

In order to identify the motivations to adopt GS, we made a list of all such motivations identified in the prior literature. Using an inductive method, the motivations were grouped in categories as can be seen in Table 3.

\begin{tabular}{|c|c|}
\hline Constructs & Motivations \\
\hline $\begin{array}{l}\text { Motivations related to } \\
\text { comparative advantages }\end{array}$ & $\begin{array}{ll}- & \text { Total acquisition cost reduction } \\
\text { - } & \text { Incoming goods have lower costs in local currency (exchange rates) }\end{array}$ \\
\hline $\begin{array}{l}\text { Motivations related to } \\
\text { competitive advantages }\end{array}$ & $\begin{array}{ll}\text { Product-related } \\
\text { - } & \text { Access new technologies } \\
\text { - } & \text { Deliver improvement } \\
\text { - } & \text { Plexibility to change input's features } \\
\text { - } & \text { Quality improvement } \\
\text { - } & \text { Quality control improvement } \\
\text { Supplier-related } & \text { Establishment of alternative supply sources } \\
\text { - } & \text { Increase in the number of available suppliers } \\
\text { - } & \text { Supplier reliability improvement } \\
\text { Process-related } & \text { Access advantages from supplier's market } \\
\text { - } & \text { Access advantages from supplier's core competence } \\
\text { - } & \text { Anticipate material needs for new products in development } \\
\text { - } & \text { Anticipate material needs in case of demand changes } \\
\text { - } & \text { Better negotiating conditions } \\
\text { - } & \text { Introduce competition among suppliers } \\
\text { - } & \text { Reduce product development cycle } \\
\text { Company-related } \\
- & \text { Customer service improvement } \\
\text { - } & \text { Establish presence in global market } \\
\text { - } & \text { Obtaining the opportunity to sell to a specific market or country } \\
\text { - } & \text { Meet supply constraints imposed by government } \\
\text { - } & \text { Offer global support for local products } \\
\text { - } & \text { React to competitors' practices } \\
\text { - } & \text { Support the company's international operations }\end{array}$ \\
\hline
\end{tabular}

Figure 3 - Motivations to adopt GS

Source references: Monczka and Trent, 1991; Bozarth, Handfield, and Das, 1998; Cho and Kang, 2001;

Christopher, 2002; Jin, 2004; Agndal, 2006; Harris, 2006; Knudsen and Servais, 2007; Dutton, 2008. 
The four investigated companies showed motivations related to comparative reasons (such as cost reduction) within the overall motivations that led them to source abroad; however, motivations related to comparative advantage were not enough to adopt GS. All companies commented on the importance of competitive advantages as types of motivation. Table 4 summarizes these motivations. Because other motivations that were not identified in the literature review were identified from the interviews with the companies, a fifth category, "other motivations," was included.

\begin{tabular}{|c|c|c|c|c|}
\hline & Company A & Company B & Company C & Company D \\
\hline Product-related & $\begin{array}{l}\text { Access to new } \\
\text { technologies } \\
\text { Delivery } \\
\text { improvement }\end{array}$ & $\begin{array}{l}\text { Access to new } \\
\text { technologies }\end{array}$ & $\begin{array}{l}\text { Access to new } \\
\text { technologies }\end{array}$ & $\begin{array}{l}\text { Access to new } \\
\text { technologies }\end{array}$ \\
\hline Supplier-related & & & $\begin{array}{l}\text { The establishment } \\
\text { of alternative } \\
\text { supply sources }\end{array}$ & \\
\hline Process-related & $\begin{array}{l}\text { Reduction of } \\
\text { product } \\
\text { development cycle }\end{array}$ & $\begin{array}{l}\text { Anticipating } \\
\text { material needs for } \\
\text { new products in } \\
\text { development }\end{array}$ & $\begin{array}{l}\text { Better negotiating } \\
\text { conditions }\end{array}$ & \\
\hline Company-related & $\begin{array}{l}\text { The establishment } \\
\text { of a presence in } \\
\text { the global market } \\
\text { Obtaining the } \\
\text { opportunity to sell } \\
\text { to a specific } \\
\text { market or country } \\
\text { Reaction to } \\
\text { competitors' } \\
\text { practices }\end{array}$ & $\begin{array}{l}\text { Reaction to } \\
\text { competitors' } \\
\text { practices }\end{array}$ & $\begin{array}{l}\text { The establishment } \\
\text { of a presence in } \\
\text { the global market } \\
\text { Obtaining the } \\
\text { opportunity to sell } \\
\text { to a specific } \\
\text { market or country }\end{array}$ & $\begin{array}{l}\text { The establishment } \\
\text { of a presence in } \\
\text { the global market }\end{array}$ \\
\hline $\begin{array}{l}\text { Other } \\
\text { motivations }\end{array}$ & $\begin{array}{l}\text { Offering } \\
\text { diversified } \\
\text { products using the } \\
\text { distribution } \\
\text { channels already } \\
\text { developed by the } \\
\text { company }\end{array}$ & $\begin{array}{l}\text { Offering } \\
\text { diversified } \\
\text { products using the } \\
\text { distribution } \\
\text { channels already } \\
\text { developed by the } \\
\text { company }\end{array}$ & & $\begin{array}{l}\text { Offering } \\
\text { diversified } \\
\text { products using the } \\
\text { distribution } \\
\text { channels already } \\
\text { developed by the } \\
\text { company }\end{array}$ \\
\hline
\end{tabular}

Figure 4 - Motivations to adopt GS related to competitive advantages

Access to new technologies is the most relevant motivation for the adoption of GS and can be related to the investigated companies' market characteristics. For example, the electrical and electronics industry has a global market with global suppliers that conduct innovation on a global basis. Motivations related to technology improvements are highlighted by Quintens, Pauwells, and Matthyssens (2006) as drivers of GS. Technology seeks to 
motivate GS; at the same time, if a company needs various technologies, these needs facilitate the adoption of GS.

Company B looked abroad for business opportunities, not just cost reductions. From the early years of the company, its entrepreneurs searched for partnerships with suppliers that could offer reduced prices and better technologies. The first supply partnership began with an Asian supplier that "had products with more technology, was smaller, and had better costs." However, even though the supplier was able to meet its needs, Company B looked for other opportunities in more advanced countries. As a result, the company established a partnership with a European company that had products with greater applied technology, despite higher prices compared to the Asian products. The reasoning behind Company B's decision was that the technologically advanced products of the European company ensured competitiveness. In addition, Company B uses its acquisitions of high-technology products to learn about them. "The technology from our suppliers (in the case of a component supplied from abroad) is improving the technology of our product (developed at the company's site in Brazil)," said one of the interviewees.

Increased numbers of technology products, when sourced globally, represent an opportunity for a company to offer new products and technologies faster compared to inhouse product development. Additionally, such an approach incorporates reduced development costs, which decrease total company costs. Thus, global suppliers dilute development costs on a global scale. Consequently, for Company D, looking abroad for new sourcing opportunities is a way of ensuring scalability by introducing global products into its portfolio. By highlighting the importance of establishing a presence in global markets, this strategy allows the company to improve its international presence.

A new motivation that has appeared from this research is the ability to offer diversified products using distribution channels that are already established. The study shows that three of the investigated companies have developed their own distribution channels; and to control them, these companies have increased the number of distributed products by introducing finished products supplied from abroad. Thus, a more effective exploration of a company's distribution channel can increase competitiveness with regard to global players (PORTER, 1986). According to Company A's interviewee, “To manufacture a product in Brazil, I need a bigger investment compared with sourcing it from China ... the investment that I could be doing in R\&D and production, including equipment, tools, and matrices, I don't need to do anymore ... I start sourcing using that amount to be able to sell these products faster.” 
The motivation to become a global player was not clearly indicated by the interviewees but can be identified through data analysis. The investigated companies have global competitors; at the same time, they wish to increase their international market share, essentially with exports. This strategy is disrupted by the need to achieve economies of scale and international presence. GS helps companies to overcome these problems because establishing a presence in the global market was the second most common motivation identified in the investigated companies' behavior.

Linder (1961) states that international trade in manufacturing differs among primary products because such trade may represent an extension across national frontiers of a country's own network of economic activity. The motivations identified in the presented cases confirm this argument because the companies consider that their markets are global and that opportunities abroad are extensions of their home markets.

International trade theory proposes that GS is not induced by price conditions; that is, other forces orient a company's behavior such as a "follow-the-leader" strategy (VERNON, 1974). In other words, companies follow the strategies developed by other companies that have already sought opportunities abroad. Vernon (1979) states that companies are "acutely myopic" because their managers tend to be stimulated by the needs and opportunities of their home markets, not the global market. For the investigated cases in this study, the adoption of GS was motivated by opportunities identified in the global market such as technology from overseas.

\section{- Risks and barriers to the adoption of GS}

The potential losses that could occur when a company adopts GS can be categorized as risks and barriers. The literature review points out that the risks from GS to a purchasing company include the possibility of a decrease in the company's agility and flexibility; an increase in distance, cost, and the number of intermediaries in the supply chain; an emphasis on specific source operations instead of the complete process, thereby reducing the ability to analyze the situation; an increase in total costs; the failure of logistics support; and difficulties dealing with cultural differences, regulations, and country uncertainty (LEVY, 1995; BOZARTH; HANDFIELD; DAS, 1998; CHO; KANG, 2001; ZENG; ROSSETI, 2003; CHRISTOPHER; PECK; TOWILL, 2006; BUTTER; LINSE, 2008; STEINLE; SCHIELE, 2008). Table 5 summarizes the findings related to the risks from GS. 


\begin{tabular}{|c|c|c|c|c|}
\hline & Company A & Company B & Company $\mathrm{C}$ & Company D \\
\hline $\begin{array}{l}\text { Environmental } \\
\text { analysis and } \\
\text { trade-off analysis }\end{array}$ & $\begin{array}{l}\text { Culture } \\
\text { Governmental } \\
\text { barriers }\end{array}$ & $\begin{array}{l}\text { Culture } \\
\text { Logistics } \\
\text { Supplier's } \\
\text { antecedents } \\
\text { Import procedures }\end{array}$ & $\begin{array}{l}\text { Exchange rate } \\
\text { Image of supplier } \\
\text { country }\end{array}$ & \\
\hline $\begin{array}{l}\text { The development } \\
\text { of alternative } \\
\text { sourcing } \\
\text { opportunities }\end{array}$ & $\begin{array}{l}\text { Alternative supplier } \\
\text { as main policy } \\
\text { (especially from } \\
\text { abroad) }\end{array}$ & $\begin{array}{l}\text { Alternative } \\
\text { supplier when } \\
\text { possible }\end{array}$ & $\begin{array}{l}\text { Alternative } \\
\text { supplier when } \\
\text { possible }\end{array}$ & $\begin{array}{l}\text { Alternative } \\
\text { supplier when } \\
\text { possible }\end{array}$ \\
\hline $\begin{array}{l}\text { Balance between } \\
\text { local and global } \\
\text { sourcing }\end{array}$ & $\begin{array}{l}\text { Reduced local } \\
\text { suppliers }\end{array}$ & $\begin{array}{l}\text { Reduced local } \\
\text { suppliers } \\
\text { Customized items }\end{array}$ & $\begin{array}{l}\text { Reduced local } \\
\text { suppliers }\end{array}$ & $\begin{array}{l}\text { Reduced local } \\
\text { suppliers }\end{array}$ \\
\hline Risk management & $\begin{array}{l}\text { Focus on cost } \\
\text { control }\end{array}$ & $\begin{array}{l}\text { Focus on cost } \\
\text { control } \\
\text { Focus on supplier } \\
\text { relationship } \\
\text { management }\end{array}$ & $\begin{array}{l}\text { Focus on supplier } \\
\text { relationship } \\
\text { management }\end{array}$ & $\begin{array}{l}\text { Focus on supplier } \\
\text { relationship } \\
\text { management }\end{array}$ \\
\hline
\end{tabular}

Figure 5 - Risks of GS

Company A believes that cultural aspects are relevant to GS but experience has considerably reduced this risk. It also points out the importance of analyzing governmental aspects even though the industry does not encounter any commercial barriers. Company B is concerned about cultural differences, the effect of which can be reduced through the centralization of GS operations by employing consultants with international expertise. Company B also focuses on the analysis of logistical aspects, the supplier's antecedents, and import procedures. Company $\mathrm{C}$ emphasizes exchange rates and the image of a supplier's country from the global perspective. Company A considers that the experience of dealing with international suppliers brings the knowledge necessary to conduct a trade-off analysis. For Company A, "The risk is inherent to the activity. ... We seek to determine whether it is worth the risk or not. ... We are helping our supplier to develop (a product that he can sell to others) but if we do not do it, we are not going to be able to offer the product in the market. ... We give the consumer a better product.”

This study identified that uncertainty is the main risk that the investigated companies incur while dealing with cultural differences and several countries. Cho and Kang (2001) suggest that companies with a low level of GS experience perceive cultural differences (language barriers, different customs, and different business practices) to be more challenging 
than companies with high or medium levels of experience. The study did not identify whether more experience in terms of time spent dealing with GS could reduce these risks. A better relationship with the suppliers and better management of this relationship can reduce the risks associated with cultural differences.

The balance between local and international sourcing was also investigated. The low number of available suppliers in the home country makes the investigation of this kind of balance more difficult. Although the case-study companies confirm the importance of having alternative suppliers, they do not place an emphasis on having them in the local market.

Barriers can be seen as factors that make it more difficult or even impossible to pursue or intensify GS. Using the approaches of Alguire, Frear, and Metcalf (1994) and Quintes, Pauwels, and Matthyssens (2006), the main barriers faced by the investigated companies were identified and are presented in Table 6.

\begin{tabular}{|c|c|c|c|c|c|}
\hline & Product & $\begin{array}{l}\text { Company/ } \\
\text { management }\end{array}$ & Network & $\begin{array}{l}\text { Industry/ } \\
\text { competition }\end{array}$ & Environment \\
\hline Internal & $\begin{array}{l}\text { Limited } \\
\text { production } \\
\text { volume (low } \\
\text { purchase } \\
\text { volume) } \\
\text { Different } \\
\text { product } \\
\text { standards } \\
\text { (customized } \\
\text { products) }\end{array}$ & $\begin{array}{l}\text { Lack of } \\
\text { resources } \\
\text { needed for GS } \\
\text { (qualified } \\
\text { professionals) } \\
\text { Accurate } \\
\text { demand forecast } \\
\text { (sales } \\
\text { fluctuation) }\end{array}$ & $\begin{array}{l}\text { Sourcing } \\
\text { requirements } \\
\text { (low stocks) }\end{array}$ & & \\
\hline External & $\begin{array}{l}\text { Delivery delays } \\
\text { (suppliers) }\end{array}$ & & $\begin{array}{l}\text { Finding } \\
\text { qualified } \\
\text { suppliers }\end{array}$ & $\begin{array}{l}\text { Intensity of } \\
\text { competition } \\
\text { (local and } \\
\text { global) }\end{array}$ & $\begin{array}{l}\text { Adverse } \\
\text { economic } \\
\text { environment } \\
\text { Language and } \\
\text { cultural } \\
\text { differences }\end{array}$ \\
\hline
\end{tabular}

Table 6 - Barriers to GS

Besides the difficulties faced by the investigated companies, none of them have a barrier analysis process formalized for product development phases. As one of Company B's interviewees states, "I think this is still a weak point, especially for new products. I think we could participate more in the initial phases to make an assessment along with $\mathrm{R} \& \mathrm{D}$ at the moment they are establishing the supplier and not just analyze the negotiation and logistics aspects."

Regarding the development of alternative sourcing opportunities, Company D notes that it is not concerned with performing environmental analyses because it does not have local 
suppliers; instead, it has to learn how to act in the global market. The Company A interviewee states that even if the company cannot find a supplier with the same quality standard, it tries to have at least one supplier already developed (with approved inputs). If possible, the company develops a supplier in Brazil. Company $\mathrm{C}$ tries to maintain an open communication flow with its suppliers in order to avoid problems with incorrect information. It has a process for double-checking information and documents. Company D takes the same approach and uses its sourcing office abroad to reduce cultural distances and improve its relationship with suppliers.

\section{- Results of the adoption of GS}

Companies that have adopted GS realize that performance improvement and cost reduction opportunities are more widely available through their sourcing efforts. They can make changes to supply items more quickly, and lead and coordinate strategic reviews more regularly in order to promote consistency by creating a common language and a way of searching for suppliers at the organizational level (TRENT; MONCZKA, 2003). They are also able to perceive better progress with their strategy implementations, deal with faster changes to product and process technologies, and observe greater similarities among key aspects of their sourcing processes across geographic locations and buying units (TRENT; MONCZKA, 2003). As Mulani (2008) emphasizes, supplier involvement helps a company to absorb knowledge, leverage capabilities, maximize contracts, and continually reduce total costs.

At the beginning of the research, we did not seek to investigate the challenges presented by the adoption of GS. During data collection, such challenges became apparent from the interviews and we decided to include them. The results achieved by the investigated companies and the challenges they face are related to the learning process that led them to develop their abilities. The findings related to the results and benefits achieved through the adoption of GS, and the challenges, are summarized in Table 7. 


\begin{tabular}{|l|l|l|l|l|}
\hline & Company A & Company B & Company C & Company D \\
\hline $\begin{array}{l}\text { Results and } \\
\text { benefits }\end{array}$ & $\begin{array}{l}\text { Global knowledge } \\
\text { Faster product } \\
\text { development }\end{array}$ & $\begin{array}{l}\text { Faster product } \\
\text { development }\end{array}$ & $\begin{array}{l}\text { Faster product } \\
\text { development } \\
\text { Access to new } \\
\text { technologies } \\
\text { The development } \\
\text { of a more complex } \\
\text { strategy }\end{array}$ & $\begin{array}{l}\text { Faster product } \\
\text { development } \\
\text { technologies }\end{array}$ \\
\hline Challenges & $\begin{array}{l}\text { The development } \\
\text { of the abilities } \\
\text { required to } \\
\text { compete for the } \\
\text { advantages that the } \\
\text { global market } \\
\text { offers }\end{array}$ & $\begin{array}{l}\text { The development } \\
\text { of the abilities } \\
\text { required to } \\
\text { compete for the } \\
\text { advantages that the } \\
\text { global market } \\
\text { offers }\end{array}$ & $\begin{array}{l}\text { The development } \\
\text { of the abilities } \\
\text { required to } \\
\text { compete for the } \\
\text { advantages that the } \\
\text { global market } \\
\text { offers }\end{array}$ & $\begin{array}{l}\text { The development } \\
\text { of the abilities } \\
\text { required to } \\
\text { compete for the } \\
\text { advantages that the } \\
\text { global market } \\
\text { offers }\end{array}$ \\
\hline $\begin{array}{l}\text { Oultural differences } \\
\text { in relationships }\end{array}$ & $\begin{array}{l}\text { Overcoming } \\
\text { cultural differences } \\
\text { in relationships }\end{array}$ & \\
\hline
\end{tabular}

Table 7 - Results achieved through GS and challenges

The use of GS as a main strategy focuses on the achievement of competitive advantages. Faster product development is one of the main results of GS adoption, according to Trent and Monczka (2003). However, such development is not perceived as an end result. The investigated companies are learning through GS, and the knowledge absorbed by them can be seen as another achieved result, as highlighted by Mulani (2008). Company A is "learning and using the expertise we have to compete together (with suppliers) and not compete (alone)." This knowledge has also allowed Company A to develop a strategy that includes the allocation of different steps of the production process to different countries. This strategy ensures faster product development, access to new technologies, and the development of a process that protects the company's product from imitators. Company B, Company C, and Company D also present cases in which the time taken for product development processes was reduced because of the partnership established with global suppliers. Company D highlights that throughout the past few years, most similar companies have gone out of business. It associates its own survival to the ability to source globally in a more effective way.

The results illustrate the challenges that these companies must be prepared to overcome. Company $\mathrm{A}$ is developing the abilities that are needed to take advantage of what the global market can offer; for example, purchasing new finished products to reverse-engineer and identifying the components and suppliers needed to develop better products. The company's 
second challenge is related to the management of its relationships with suppliers in order to ensure better inputs, commercial terms, and delivery times while simultaneously protecting the company.

Company B notes that its biggest challenge is the difficulty associated with placing orders to global suppliers because the company lacks a high and continuous volume of orders. The same challenge is faced by Company D. Another challenge presented by Company B is how to deal with long lead-times. In this regard, large stockpiles can develop when technology changes. Because its products relate directly to innovation, if Company B identifies an opportunity for product improvement that generates the need to modify a component, it must consider the possible stockpiling of old inputs. Such stockpiling is often on a larger scale when dealing with international supplies rather than local. Company $\mathrm{C}$ considers that the ability to overcome cultural differences in relationships with suppliers is a consequence of the knowledge developed from global exposure: "Some things we learned after years (of global exposure)." Company D's interviewee argues that "challenges are permanent. ... Just as the technologies change, the components change. The search for new components is continuous, as the old ones become obsolete. This is a permanent situation."

\section{FINAL DISCUSSION}

According to the case studies, the companies adopted GS because they were motivated by gaining faster access to new technologies, establishing a presence in global markets, and becoming global players. These three motivations indicate that opportunities to achieve competitive advantages are the main reasons to adopt GS, although the companies also identified total cost reduction as a relevant factor. The adoption of GS was conceived as a way to address dependency and transform the need to import into an opportunity to become more competitive than local rivals. Essentially, GS represents a way to improve innovation in the selected companies through faster product development and the introduction of more products into their distribution channels. GS is also regarded as a means of integrating innovation activities (products, logistics, materials, and suppliers). The research findings challenge those of Alguire, Frear, and Metcalf (1994), for whom GS may not be an effective method for companies whose products are subject to design changes and whose production volumes are low. However, the need for faster innovation is one of the motivations identified in the examined cases, and the possibility of improving innovation through a global supplier base helps create competitive advantage because of a reduction in development costs and time. 
A benefit achieved by the investigated companies that has not been identified in the literature is the importance of joint development and the absorption of knowledge from the supplier base. The companies do not use a broad base of suppliers to implement their strategies; instead, they use their suppliers to develop market strategies. These findings confirm Chen, Paulraj, and Lado's (2004) research, which suggests that competitive advantages can be achieved by enabling companies to form close working relationships more quickly with a limited number of suppliers. This approach promotes open communication among supply chain partners and facilitates the development of long-term strategic relationships that are oriented to achieving mutual gains.

However, the investigated companies face difficulties, especially with regard to cultural differences. In order to avoid supplier dependency, they have found alternative suppliers, either abroad or in the local markets. In this context, the difficulty in dealing with the uncertainty associated with cultural differences is a risk factor. However, better relationships with suppliers and better relationship management were identified as ways to reduce this risk.

\subsection{THEORY IMPLICATIONS}

The results of this research imply that GS is related to technological innovation and reductions in product development time and time to market. Innovation can also result from access to a supplier's technology. In this regard, innovation could be related not only to new products but also to the overall development of a company because of the potential for learning from suppliers. These findings, achieved through empirical research, could represent the identification of a gap in prior theory.

With regard to the internationalization process, the study found that the investigated companies are developing into distributors in the Brazilian market as well as being manufacturers. In general terms, the production outsourcing process has been identified in companies operating in several industrial sectors such as footwear, which is not as technology-intensive as the electrical and electronics industry. The presence of this process in the latter industry, which is one based on technology in terms of the maintenance or development of products and their components, is a new aspect of internalization studies. This finding, achieved through empirical research, represents the identification of a gap in prior theory.

The statement by Rugman (1980) that the activities of global companies are better explained by the theory of internalization rather than the theory of internationalization is an interesting perspective from which to understand the companies investigated in this study and 
their international behavior. Buckley and Carson (1976) say that the internationalization of knowledge in the global market represents an opportunity to visualize how a company can grow by exploring the various opportunities present in different countries. In other words, to achieve a final product in a given development process, units from around the world may be involved. The investigated companies presented behaviors that confirm that the knowledge acquired through international exposure improves the adoption of GS. In part, this improvement is a consequence of the development of relationships with suppliers in global markets.

Based on the research findings, a set of research insights was developed as presented below.

GS is motivated by the opportunity to offer diversified products using distribution channels already developed by a company.

A reduced number of available local suppliers diminishes the importance of alternative suppliers' development and the importance of performing environmental analysis.

The development of specific capabilities related to GS adoption can improve the results achieved by companies.

\subsection{STUDY LIMITATIONS AND FUTURE RESEARCH DIRECTIONS}

Using four case studies from the same industry is a limitation of this research. The electrical and electronics industry depends greatly on global suppliers. If the research had been conducted on an industry that has competitive local suppliers, the findings could have been different, a situation that indicates the need for investigations based on different conditions and industries. The lack of local suppliers in the investigated industrial sector reduces the opportunities to develop different sourcing strategies and must be viewed as a characteristic of the industry.

The risks related to GS, especially with regard to knowledge transfer, are inherent. Companies run these risks because conducting GS and joint development with suppliers is a means by which such companies can offer certain products to customers that they would otherwise be unable to develop at the same levels of quality and cost by themselves. The development of trust can be a way to reduce the risks; in this regard, the research has identified that future studies could investigate the role of trust within GS. The need to conduct future research related to innovation and GS has also been identified here. A final 
recommendation is to consider the relationship between the internationalization process and the role of GS in the context of export improvement.

\section{REFERENCES}

AGNDAL, $\mathrm{H}$. The purchasing entry process: a study of 10 Swedish industrial small and medium-sized enterprises. Journal of Purchasing \& Supply Management, v. 12, p. 182196, 2006.

ALGUIRE, M. S.; FREAR, C. R.; METCALF, L. E. An examination of the determinants of global sourcing strategy. Journal of Business and Industrial Marketing, v. 9, n. 2, p. 62-75, 1994.

BARRAT, M.; CHOI, T.Y.; LI, M. Qualitative case studies in operations management: Trends, research outcomes, and future research implications. Journal of Operations Management, v. 29, p. 329-342, 2011.

BARRETO, A.; ROCHA, A. Por que as empresas brasileiras não se internacionalizam? In: ROCHA, A. (Ed.). As novas fronteiras: a multinacionalização das empresas brasileiras. Rio de Janeiro: Mauad, 2003.

BERNSTEIN, M. The on-going management of international sourcing. World Trade, v. 20, n. 4, p. 54-56, 2007.

BORINI, F. M. et al. First movers x late movers: estudo de casos da indústria de cimentos. In: FLEURY, A.; FLEURY, M. T. L. (Org.). Internacionalização e os países emergentes. São Paulo: Atlas, 2007.

BOZARTH, C.; HANDFIELD, R.; DAS, A. Stages of global sourcing strategy evolution: an exploratory study. Journal of Operation Management, v. 16, p. 241-255, 1998.

BUCKLEY, P. J.; CASSON, M. The future of the multinational enterprise. 1976.

BUTTER, F. A. G.; LINSE, K. A. Rethinking procurement in the era of globalization. MIT Sloan Management Review, v. 50, n. 1, p. 75-80, 2008.

CHEN, I. J.; PAULRAJ, A.; LADO, A. A. Strategic purchasing, supply management, and firm performance. Journal of Operations Management, v. 22, p. 505-523, 2004

CHO, J.; KANG, J. Benefits and challenges of global sourcing: perceptions of US apparel retail firms. International Marketing Review, v. 18, n. 5, p. 542-561, 2001.

CHRISTOPHER, M. Logística e gerenciamento da cadeia de suprimentos. São Paulo: Pioneira Thomson Learning, 2002.

CHRISTOPHER, M.; PECK, H.; TOWILL, D. A taxonomy for selecting global supply chain strategies. The International Journal of Logistics Management, v. 17, n. 2, p. 277-287, 2006.

DUTTON, G. Ten reasons to use global sourcing. World Trade, n. 21, v. 6, 2008. 
FLEURY, A.; FLEURY, M. T. L. Internacionalização das empresas brasileiras: em busca de uma abordagem teórica para os late movers. In: (Org.).

Internacionalização e os países emergentes. São Paulo: Atlas, 2007.

GAMMELTOF, P.; BARNARD, H.; MADHOCK, A. Emerging multinationals, emerging theory: Macro and micro-level perspectives. Journal of International Management, v. 16, n. 2, p. 95-101, 2010.

HARRIS, G. L. The essence of global sourcing. Contract Management, v. 46, n. 3, p. 16-21, 2006.

KAUSIK, U.; MAHADEVAN, B. A Review of strategic sourcing literature during 19972010: trends and emerging issues for research. South Asian Journal of Management, v. 19, n. 2, p. 78-99, 2012.

KNUDSEN, M. P.; SERVAIS, P. Analysing internationalization configurations of SMES's: the purchaser's perspective. Journal of Purchasing \& Supply Management, v. 13, n. 2, p. 137-151, 2007.

KOCABASOGLU, C.; SURESH, N. C. Strategic sourcing: an empirical investigation of the concepts and its practices in U.S. manufacturing firms. Journal of Supply Chain Management, v. 42, n. 2, p. 4-16, 2006.

KOTABE, M. Global sourcing and value creation: opportunities and challenges. Journal of International Management, v. 15, p. 121-125, 2009.

KOTABE, M; MURRAY, J. Y. Global sourcing strategy and sustainable competitive advantage. Industrial Marketing Management, v. 33, p. 7-14, 2004.

LAHIRI, S.; KEDIA, B. L. The effects of internal resources and partnership quality on firm performance: an examination of Indian BPO Providers. Journal of International Management, v. 15, n. 2, p. 209-224, 2009.

LEVY, D. L. International sourcing and supply chain stability. Journal of International Business Studies, v. 26, p. 343-360, 1995.

LI, J.; YAO, F. K. The role of reference groups in international decisions by firms from emerging economies. Journal of International Management, v. 16, n. 2, p. 519-540, 2010.

LINDER, S. B. An essay on trade and transformation: an excerpt. 1961.

MONCZKA, R. M.; TRENT, R. J. Global sourcing: a development approach. International Journal of Purchasing and Materials Management, v. 27, n. 2, p. 2-8, 1991.

MULANI, N. Five "good behaviors" that are key to global sourcing. Logistics Management, v. 47, n. 6, 2008.

NASSIMBENI, G. International Sourcing: Empirical Evidence from a sample of Italian Firms. International Journal of Production Economics, v. 103, p. 694-706, 2006

NARASIMHAN, R.; CARTER, J. R. Linking business unit and material sourcing strategies. Journal of Business Logistics, v. 19, n. 2, p. 155-171, 1998. 
NASSIMBENI, G.; SARTOR, M. Sourcing in China: a typology. International Journal of Production Economics, v. 107, p. 333-349, 2007.

NUNES, M. P.; VIEIRA, L. M.; ANTUNES JR., J. A. V. The adoption of global Sourcing by a Brazilian company. Journal of Operations and Supply Chain Management, v. 6, n. 2, p. 114-127, 2013

PORTER, M. E. Competition in global industries. Boston, MA: Harvard Business School Press, 1986.

QUINTENS, L.; PAUWELS, P.; MATTHYSSENS, P. Global purchasing strategy: conceptualization and measurement. Industrial Marketing Management, v. 35, p. 881-891, 2006.

ROCHA, A.; SILVA, J. F.; CARNEIRO, J. Expansão internacional das empresas brasileiras: revisão e síntese. In: FLEURY, A.; FLEURY, M. T. L. (Orgs.). Internacionalização e os países emergentes. São Paulo: Atlas, 2007.

RUGMAN, A. A new theory of the multinational enterprise: internationalization versus internalization. Columbia Journal of World Business, v. 15, n. 1, p. 23-29, 1980.

SAMLI, A. C.; BROWNING, J. M. Developing competitive advantage. Journal of Global Marketing, v. 16, n. 4, p. 35-52, 2003.

SAMLI, A. C., BROWNING, J. M., BUSBIA, C. The status of global sourcing as a critical tool of strategic planning; opportunistic versus strategic dichotomy. Journal of Business Research, v. 43, n. 3, p. 177-197, 1998.

SHETH, J. N.; SHARMA, A. Supplier relationships: emerging issues and challenges. Industrial Marketing Management, v. 26, p. 91-100, 1997.

SIRKIN, H. L.; HERMELING, J. W.; BHATTACHARYA, A. K. Globality: challenger companies re radically redefining the competitive landscape. Strategy \& Leardership, v. 36, n. 6, p. 36-41, 2008.

STEINLE, C.; SCHIELE, H. Limits to global sourcing? Strategic consequences of dependency on international supplier: Cluster theory, resource-based view and case studies. Journal of Purchasing and Supply Management, v. 14, n. 1, p. 3-14, 2008.

TOWERS, N.; SONG, Y. Assessing the future challenges in strategic sourcing commodity from China: a case-study analysis. Asia Pacific Business Review, v. 16, p. 527-544, 2010.

TRAUTMANN, G.; BALS, L.; HARTMANN, E. Global sourcing in integrated network structures: the case of hybrid purchasing organizations. Journal of International Management, v. 15, n. 2, p. 194-208, 2009.

TRENT, R. J. Understanding integrated global sourcing. International Journal of Physical Distribution \& Logistics Management, v. 33, n. 7, p. 607-629, 2003a.

TRENT, R. J.; MONCZKA, R. M. International purchasing and global sourcing: what are the differences? Journal of Supply Chain Management, v. 39, n. 4, p. 26-36, 2003. 
VERNON, R. The location of economic activity In: DUNNING, J. H. Analysis and the Multinational Enterprise. London: George Allen \& Unwin, Ltd., 1974. p. 89-114, 1974.

The product cycle hypothesis in a new international environment. Oxford Bulletin of Economics and Statistics, v. 41, p. 255-67, nov. 1979.

ZENG, A. Z.; ROSSETTI, C. Developing a framework for evaluating the logistics costs in global sourcing process. International Journal of Physical Distribution and Logistics Management, v. 33, n. 9, p. 785-803, 2003. 